J. Asiat. Soc. Bangladesh, Sci. 46(2): 179-189, December 2020

\title{
BREEDING BIOLOGY OF THE RED-WHISKERED BULBUL, PYCNONOTUS JOCOSUS (LINNAEUS, 1758) IN MADHUPUR NATIONAL PARK, BANGLADESH
}

\author{
SHAWKAT IMAM KHAN ${ }^{1}$ AND HABIBON NAHER ${ }^{2}$ \\ ${ }^{1}$ Department of Natural History, Bangladesh National Museum, \\ Dhaka-1000, Bangladesh \\ ${ }^{2}$ Department of Zoology, Jagannath University, Dhaka-1100, Bangladesh
}

\begin{abstract}
Breeding biology of the Red-whiskered Bulbul, Pycnonotus jocosus (Linnaeus, 1758) in Madhupur National Park (MNP), Bangladesh, was carried out from January to June in 2009. The breeding season lasted from February to May. Both the parents built a hollow cup-shaped nest, the weight, length, and depth of which were respectively, 9.9-12 $\mathrm{g}$ $(10.98 \pm 0.78 \mathrm{~g}), 8-10 \mathrm{~cm}(8.98 \pm 0.67 \mathrm{~cm})$, and $4.1-5 \mathrm{~cm}(4.62 \pm 0.312 \mathrm{~cm})$. The outer and inner diameter of the nest opening was $8-9.7 \mathrm{~cm}(8.92 \pm 0.54 \mathrm{~cm})$ and $6-7.5 \mathrm{~cm}(6.72 \pm 0.49$ $\mathrm{cm})$, respectively. The height of the nest from the ground ranged from 0.6-2.1 m $(1.41 \pm 0.55 \mathrm{~m})$. They took $14-16$ days $(15 \pm 0.85$ days $)$ in nest building and laid $2-4$ $(2.74 \pm 0.81)$ whitish with brown blotched eggs. The egg size was $2.10 \times 1.45 \mathrm{~cm}$. The hatchlings hatched out after 12-15 days (13.14 \pm 1.17 days) of incubation period and fledged between 13-18 days (14.85 \pm 1.77 days) after hatching. The breeding success was $81.82 \%$ in relation to nestlings hatched and $51.92 \%$ in relation to eggs laid. Infertility $(47.36 \%)$ was the leading cause of egg loss and stolen $(66.67 \%)$ for nestlings.
\end{abstract}

Key words: Breeding season, Nestling, Fledging, Red-whiskered Bulbul

\section{Introduction}

Red-whiskered Bulbul (Picnonotus jocosus) is a common resident bird of Bangladesh (IUCN Bangladesh 2015). It belongs to the Family Pycnonotidae and Order Passeriformes. Its global range extends through South, East, and South-east Asia (IUCN Bangladesh 2015). In Bangladesh, it occurs in different habitat types (IUCN Bangladesh 2015). It inhabits forests, gardens, orchards, and bushy areas, including villages and towns (Siddiqui et al. 2008). It is seen in pairs or loose feeding flocks in lightly wooded areas and open country with bushes and shrubs and farmland (IUCN Bangladesh 2015). It feeds mainly on drupes, berries, figs, flower-buds, nectar, soft bodied insects such as

\footnotetext{
${ }^{1}$ Author for correspondence: <shawkat194@gmail.com>.
} 
caterpillars, ants, and spiders (Siddiqui et al. 2008). It is one of the most common and important seed dispersal agents in anthropogenic open habitats in tropical Asia (Corlett 1998). However, information on the breeding biology of this species is limited in Bangladesh. Information on breeding ecology is found at Lucknow in India (Mazumdar and Kumar 2007) and south-west China (Li et al. 2015). Hence, we aimed to collect detailed information on the breeding biology of this species in a deciduous forest, which may be the baseline information in Bangladesh.

\section{Material and Methods}

Study area: The study was carried out at Madhupur National Park (MNP) (243' to $24^{\circ} 42^{\prime} \mathrm{N}, 90^{\circ} 00^{\prime}$ to $90^{\circ} 06^{\prime} \mathrm{E}$ ), Tangail, Bangladesh (Fig. 1) from January to June in 2009. The total area of the park is 8,430 ha (Khan and Ahsan 2011). This is situated in the northern part of Bhawal-Madhupur Sal (Shorea robusta) forest tract, $50 \mathrm{~km}$ south of the Garo Hills of the Meghalaya State of India, and about $151 \mathrm{~km}$ north of Dhaka (Khan and Ahsan 2015), the capital of Bangladesh. The park's altitude is about $20 \mathrm{~m}$ above the mean sea level (Monirujjaman and Khan 2018).

The park is within the administrative District of Tangail except for a portion of the southeast corner that falls in the Mymensingh District. The park forms a slightly elevated tract of approximately 1-2 $\mathrm{m}$ in height over the surrounding plains. There are numerous depressions with gentle slopes intercepting the ridges, which runs north to south, forming the irregular masses of high lands with gentle slopes (Ismail and Mia 1973). In the rainy season, the low-lying depressions in the park accumulate water and become marshy. These marshy places dry up in summer and winter seasons, but they expand into broad, shallow areas in the rainy season. The forest is partly dense, partly thin, and there are scrub jungles also (Khan and Ahsan 2015). The climate is moderate with warm weather from March to October; the maximum temperature is $37.6^{\circ} \mathrm{C}$ in April. The cold weather lasts from November to February with a minimum temperature of $7.8^{\circ} \mathrm{C}$. The annual average rainfall is $2,091 \mathrm{~mm}$. Maximum humidity varies from 97 to $100 \%$ and a minimum of 20 to 58\%. Madhupur National Park is dominated by Sal (Shorea robusta) trees associated with other deciduous plant species (Khan and Ahsan 2015).

To find out the nest and nesting trees, the area was surveyed through a transect line with the help of local field assistance. A total of $28 \mathrm{~km}$ transects were covered to find out the nest (Table 1). A total of 19 nests were identified during the nest building and egg laying period. While a nest was located, the GPS location was recorded. Nest characteristics were noted on unused nests (nesting materials, nest height from the ground, the outer and 
inner diameter of the nest opening, depth of the nest cup) after fledging. Altogether, 15 nests were followed to record the nest building period. The nest was visited a week thrice to record the egg-laying time, clutch size, egg measurements, incubation period, hatching time, hatchling number, hatchling measurements, fledgling number, and fledging date. Fourteen nests were examined to find out the incubation period and 27 nestlings were monitored for fledgling period. A total of 52 eggs and 33 hatchlings were measured to find out the egg and hatchlings size respectively. Food items provisioned to the nestlings by the parents were also recorded. Stolen of nestling by local urchins' and any sign of nest destruction was also recorded.

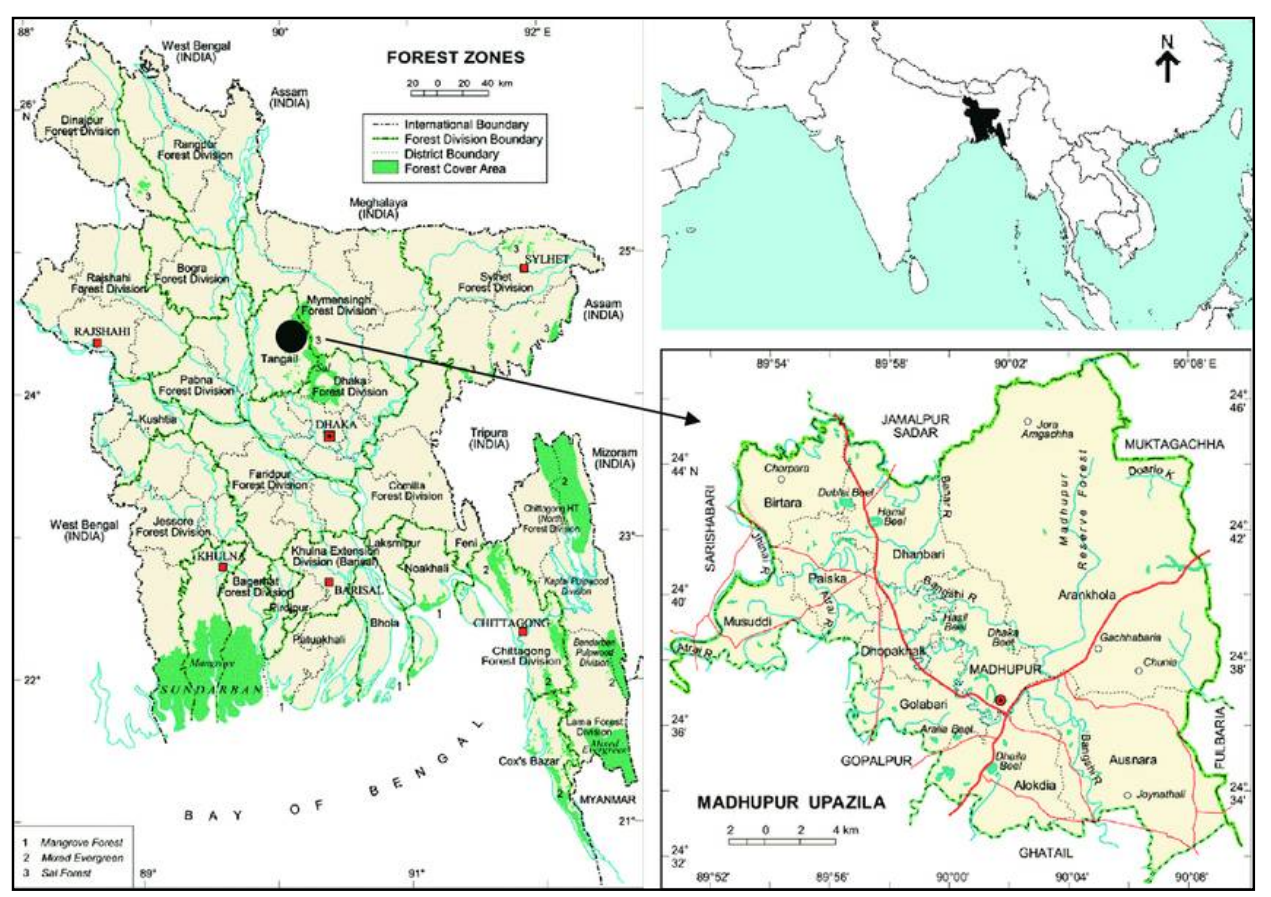

Fig. 1. Location of the Madhupur National Park (Islam et al. 2014).

A digital electronic scale $(500 \mathrm{~g} \times 0.1 \mathrm{~g})$ was used to weigh the nestling, fledgling, and unused nest after fledging, a slide caliper to take egg and nestling measurement, meter tape $(1 \mathrm{~cm}$ to $50 \mathrm{~m})$ to measure the nest height from the ground, binoculars (Bushnell $10 \times 42$ ) to monitor the nest and behaviour of the parents from a safe distance and GPS 
(Garmin etrex 8) machine to take GPS of the nest site and to measure transect length during the study period.

Table 1. Length of transects used during the study period.

\begin{tabular}{|c|c|c|c|c|}
\hline \multirow{2}{*}{$\begin{array}{l}\text { Transect } \\
\text { number }\end{array}$} & \multirow[t]{2}{*}{ Transect site } & \multirow{2}{*}{$\begin{array}{c}\text { Transect } \\
\text { length } \\
(\mathrm{km})\end{array}$} & \multicolumn{2}{|c|}{ GPS location } \\
\hline & & & Start Point & End Point \\
\hline 1 & $\begin{array}{l}\text { National park main gate, Rasulpur } \\
\text { to Dokhola beat forest gate }\end{array}$ & 8 & $\begin{array}{l}24^{\circ} 41 ' 20.16^{\prime \prime} \mathrm{N} \\
90^{\circ} 8121.25^{\prime \prime} \mathrm{E}\end{array}$ & $\begin{array}{l}24^{\circ} 42^{\prime} 34.18^{\prime \prime} \mathrm{N} \\
90^{\circ} 3{ }^{\prime} 58.44^{\prime \prime} \mathrm{E}\end{array}$ \\
\hline 2 & $\begin{array}{l}\text { Dokhola beat forest gate to } \\
\text { Pochish mail bazar }\end{array}$ & 9 & $\begin{array}{l}24^{\circ} 42^{\prime} 34.18^{\prime \prime} \mathrm{N} \\
90^{\circ} 3{ }^{\prime} 58.44 " \mathrm{E}\end{array}$ & $\begin{array}{l}24^{\circ} 38^{\prime} 44.55^{\prime \prime} \mathrm{N} \\
90^{\circ} 4^{\prime} 41.62^{\prime \prime} \mathrm{E}\end{array}$ \\
\hline 3 & $\begin{array}{l}\text { Rasulpur Mazar to Pochish mail } \\
\text { bazar }\end{array}$ & 9 & $\begin{array}{l}24^{\circ} 41 ' 20.16^{\prime \prime} \mathrm{N} \\
90^{\circ} 8 ' 21.25^{\prime \prime} \mathrm{E}\end{array}$ & $\begin{array}{l}24^{\circ} 38^{\prime} 44.55^{\prime \prime} \mathrm{N} \\
90^{\circ} 4^{\prime} 41.62^{\prime \prime} \mathrm{E}\end{array}$ \\
\hline 4 & $\begin{array}{l}\text { Bangladesh Air Force Firing range } \\
\text { road }\end{array}$ & 1 & $\begin{array}{l}24^{\circ} 40^{\prime} 40.50 " \mathrm{~N} \\
90^{\circ} 70^{\prime} 38.70^{\prime \prime} \mathrm{E}\end{array}$ & $\begin{array}{l}24^{\circ} 40^{\prime} 06.92^{\prime \prime} \mathrm{N} \\
90^{\circ} 07^{\prime} 42.05^{\prime \prime} \mathrm{E}\end{array}$ \\
\hline 5 & Rasulpur to Kathalia village & 1 & $\begin{array}{l}24^{\circ} 41 ' 20.16^{\prime \prime} \mathrm{N} \\
90^{\circ} 08^{\prime} 21.25^{\prime \prime} \mathrm{E}\end{array}$ & $\begin{array}{l}24^{\circ} 40^{\prime} 28.16^{\prime \prime} \mathrm{N} \\
90^{\circ} 08^{\prime} 41.96 " \mathrm{E}\end{array}$ \\
\hline
\end{tabular}

Windows spreadsheet program Excel was used to do all the computations and numerical analyses. All the mean values are provided with standard deviations. The breeding success was calculated by using the following formulae:

Hatching success $(\%)=($ No. of eggs hatched $/$ total no. of eggs laid $) \times 100$

Fledging success $(\%)=($ No. of nestlings fledged $/$ total no. of nestlings hatched $) \times 100$

Breeding success $(\%)=($ No. of eggs laid $/$ No. of nestlings fledged $) \times 100$

\section{Result and Discussion}

Breeding season: The breeding season was recorded from February to May in the Madhupur National Park. It was somewhat later (March to September) in Bangladesh compared to Siddiqui et al. (2008). The breeding season varied in different countries of the world. It was mid-February to May in Florida (Florida Fish and Wildlife Conservation Commission 2003), March to July in the north of India, December to June in south India with the second period in September after the monsoon (Riper et al. 1979), August to March in Australia (Australian Museum 2020), February to August at Xishuangbanna Tropical Botanical Garden in southwest China (Li et al. 2015). Ali and Ripley (1971) stated that they breed in March, chiefly April in India. 
Nesting tree and nest site: Nests were built on low forked branches of available shrubs or small trees in bushes. Low tree fork was also reported as a nest site in Sydney (Australian Museum 2020). Virtually shrubs, hedges, or small trees within suburbs were used as a nesting site in Florida (Carleton and Owre 1975). Shrubs or small trees were reported as a nesting site in Florida (Florida Fish and Wildlife Conservation Commission 2003). Nests in low bushes or creepers were observed by Siddiqui et al. (2008).

In MNP, this bird was noted to prefer to build its nest at roadside bushes of the forest apart from human habitation (Table 2). Baker (1922) mentioned that this species selected garden and cultivated lands for its abode; breeding excursions into jungle and forest are rare.

Table 2. GPS of the nesting sites.

\begin{tabular}{ccc}
\hline \multirow{2}{*}{ Nest no } & \multicolumn{2}{c}{ GPS } \\
\cline { 2 - 3 } & $\mathrm{N}$ & $\mathrm{E}$ \\
\hline 1 & $24^{\circ} 41^{\prime} 49.47^{\prime \prime}$ & $90^{\circ} 07^{\prime} 41.59^{\prime \prime}$ \\
2 & $24^{\circ} 41^{\prime} 17.93^{\prime \prime}$ & $90^{\circ} 08^{\prime} 29.31^{\prime \prime}$ \\
3 & $24^{\circ} 40^{\prime} 41.03^{\prime \prime}$ & $90^{\circ} 07^{\prime} 37.77^{\prime \prime}$ \\
4 & $24^{\circ} 41^{\prime} 23.70^{\prime \prime}$ & $90^{\circ} 08^{\prime} 03.39^{\prime \prime}$ \\
5 & $24^{\circ} 41^{\prime} 41.37^{\prime \prime}$ & $90^{\circ} 066^{\prime} 35.88^{\prime \prime}$ \\
6 & $24^{\circ} 42^{\prime} 07.74^{\prime \prime}$ & $90^{\circ} 04^{\prime} 57.48^{\prime \prime}$ \\
7 & $24^{\circ} 40^{\prime} 21.56^{\prime \prime}$ & $90^{\circ} 07^{\prime} 57.48^{\prime \prime}$ \\
8 & $24^{\circ} 40^{\prime} 21.86^{\prime \prime}$ & $90^{\circ} 06^{\prime} 44.54^{\prime \prime}$ \\
9 & $24^{\circ} 41^{\prime} 11.14^{\prime \prime}$ & $90^{\circ} 08^{\prime} 07.22^{\prime \prime}$ \\
10 & $24^{\circ} 41^{\prime} 22.28^{\prime \prime}$ & $90^{\circ} 08^{\prime} 03.01^{\prime \prime}$ \\
11 & $24^{\circ} 41^{\prime} 43.11^{\prime \prime}$ & $90^{\circ} 04^{\prime} 55.54^{\prime \prime}$ \\
12 & $24^{\circ} 40^{\prime} 20.14^{\prime \prime}$ & $90^{\circ} 07^{\prime} 44.79^{\prime \prime}$ \\
14 & $24^{\circ} 41^{\prime} 04.62^{\prime \prime}$ & $90^{\circ} 07^{\prime} 55.34^{\prime \prime}$ \\
15 & $24^{\circ} 40^{\prime} 58.36^{\prime \prime}$ & $90^{\circ} 08^{\prime} 31.30^{\prime \prime}$ \\
16 & $24^{\circ} 39^{\prime} 40.13^{\prime \prime}$ & $90^{\circ} 05^{\prime} 20.11^{\prime \prime}$ \\
17 & $24^{\circ} 40^{\prime} 01.43^{\prime \prime}$ & $90^{\circ} 05^{\prime} 46.97^{\prime \prime}$ \\
18 & $24^{\circ} 39^{\prime} 19.29^{\prime \prime}$ & $90^{\circ} 05^{\prime} 04.82^{\prime \prime}$ \\
19 & $24^{\circ} 39^{\prime} 06.77^{\prime \prime}$ & $90^{\circ} 04^{\prime} 36.39^{\prime \prime}$ \\
\hline
\end{tabular}

Nest building: Both the partners took part in the nest building. During nest building, when one partner was busy to place the nesting materials, the other partner flew away to 
collect nesting materials. They used their beak to place nesting materials in a crisscross way and rubbing their breast and belly inside the nest to make it cup shape. They put cobweb around the rim to bind the materials tightly and placed the soft, thin fiber inside the nest's cup. Sharing nest building by both partners was also reported by Mazumdar and Kumar (2007). Sharing nest building was also reported in other birds (Naher et al. 2009, Naher 2012).

Morphometric of nest: Nests were cup shaped, deeply hollow at the center (Fig. 2). Shallow cup shaped nest was also described by others in different countries (Mazumdar and Kumar 2007, Siddiqui et al. 2008 and Li et al. 2015).

The vertical length of the outer layer of the nest was $8-10 \mathrm{~cm}(8.98 \pm 0.67 \mathrm{~cm})$. The present study was very close to Riper et al. (1979), who found $8 \mathrm{~cm}$ length in Hawaii. The outer diameter of the nest opening in MNP was $8-9.7 \mathrm{~cm}(8.92 \pm 0.54 \mathrm{~cm})$ which was very close to the study of Riper et al. (1979) study $(8-10 \mathrm{~cm})$. The inner diameter of the nest opening was $6-7.5 \mathrm{~cm}(6.72 \pm 0.49 \mathrm{~cm})$, which was the same as the findings of Riper et al. (1979). The cup depth was $4.1-5 \mathrm{~cm}(4.62 \pm 0.312 \mathrm{~cm})$ in the present study, but Riper et al. (1979) stated a little bit larger $(5.5 \mathrm{~cm})$ depth. The weight of dry, unused nest was 9.9-12 g (10.98 $\pm 0.78 \mathrm{~g})$, but Riper et al. (1979) recorded a little bit lower (9.9 g) weight in Hawaii.

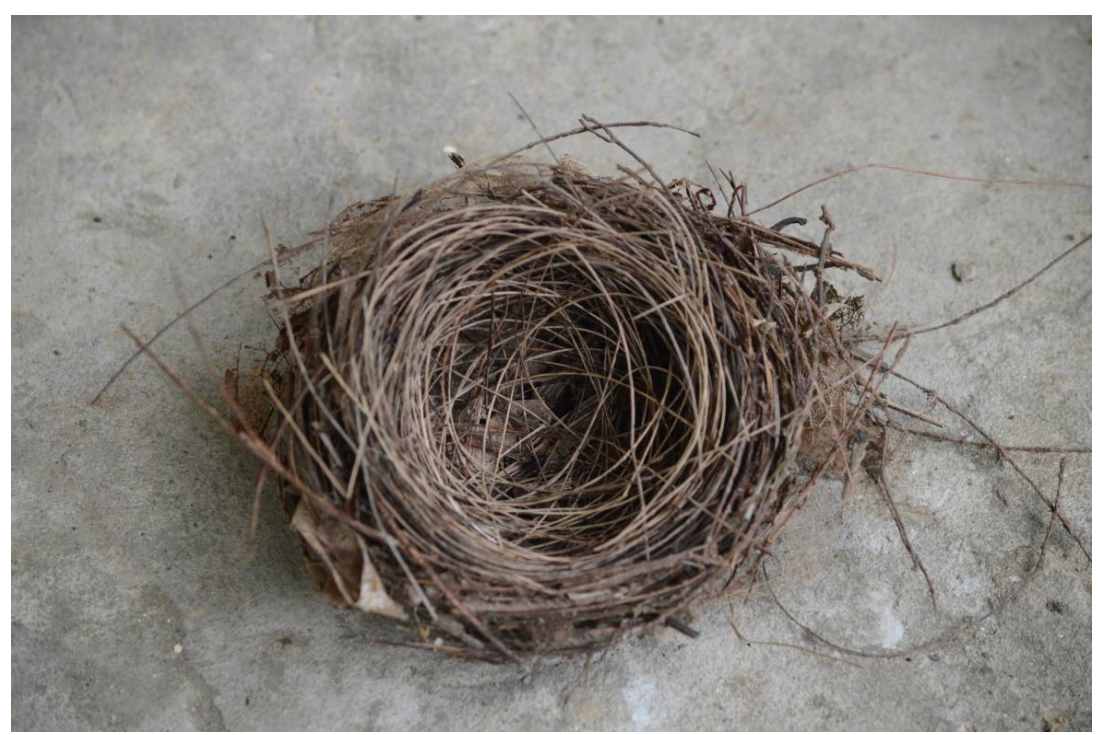

Fig. 2. Nest of a Red-whiskered Bulbul. 
Nesting materials: They used the materials to build the nests which were available surrounding the nesting sites. The nest was built with leaves, soft fibers of bamboo, twigs, cobwebs, small grasses, and different small wild plant's fibers. Various nesting materials were reported by many researchers in other study sites of the world. Siddiqui et al. (2008) reported that the nest was built up of twigs and dead leaves bound with cobwebs, especially around the rim, and lined with roots, grasses, and hairs. Florida Fish and Wildlife Conservation Commission (2003) reported that the nest is constructed of rootlets grass and the Australian pine needles and are usually embellished with bits of dried leaves, paper, plastic, snake skin, or the bark of the cajeput tree in Florida. Australian Museum (2020) noted that the nest is built up of rootlets bark, and leaves, lined with soft fiber in Sydney. According to Riper et al. (1979), the nest had a leaf base with coarse grass and flexible stems of small shrubs woven together to make a bowl, there was no cup lining tissue paper, and a strand of bark adorned the outside of the cup in Hawaii. Carleton and Owre (1975) found rootlets and grasses in the nest in Florida .

Nest height from the ground: The height of the nest from the ground ranged from 0.6-2.1 $\mathrm{m}(1.41 \pm 0.55 \mathrm{~m})$ in MNP. A very close finding (0.6-2.4 $\mathrm{m})$ was reported in Florida by Carleton and Owre (1975). But in Hawaii, the nest was built at 1.5-3.6 m above the ground (Riper et al. 1979).

Territory: During the breeding season, the male bird maintained a territory around its nesting site by chasing the intruder and by territorial song at morning and afternoon. This species uttered 'territorial song' to ensure the territory boundary at Songkhala Province in the south of Thailand (Sotthibandhu 2003). Red-whiskered Bulbuls are among the most range restricted breeding birds in Florida (Pranty 2010).

Nest building time: Both sexes took part in nest building. They took 14-16 days (15 \pm 0.85 days) to build a nest.

Clutch size: They laid one egg each day. The clutch size ranged from 2-4 (2.74 \pm 0.81$)$ in MNP. Same clutches (2-4 eggs) were found in Florida (Florida Fish and Wildlife Conservation Commission 2003), Japan (Eguchi and Amano 2004), and Australia (Australian Museum 2020). Two to three clutches were also reported in different sites (Mazumdar and Kumar 2007, Siddiqui et al. 2008, Li et al. 2015).

Egg characteristics: Egg colour was whitish with brown blotched or spotted in MNP. Brown blotched with white background eggs were also reported by Riper et al. (1979) in Hawaii. The whitish colour egg was noted in Florida (Florida Fish and Wildlife Conservation Commission 2003) but in Australia, pale pink eggs streaked and spotted with shades of red were reported (Australian Museum 2020). 
The length of eggs varied from $2-2.2 \mathrm{~cm}(2.10 \pm 0.08 \mathrm{~cm})$ and width $1.4-1.5 \mathrm{~cm}$ $(1.45 \pm 0.05 \mathrm{~cm})$ in MNP. Siddiqui et al. (2008) recorded the egg size as $2.2 \times 1.6 \mathrm{~cm}$.

Incubation and incubation period: Both the partner took part in incubation in MNP. Sharing in incubation was also presumed by Ali and Ripley (1971) in this species and Naher et al. (2009) and Naher (2012) in other species. When one bird incubated, the other stayed at the nearby branches of the nesting tree and guarded the nest. If an intruder came near the nest, the guarder made the threat call while the bird engaged in incubating escaped from the nest immediately to a hiding place.

The incubation period was $12-15$ days (13.14 \pm 1.17 days) in MNP, a little bit shorter (11 days) in Hawaii (Riper et al. 1979) but almost same (12-13 days) in Florida (Florida Fish and Wildlife Conservation Commission 2003) and in Bangladesh(12 days) (Siddiqui et al. 2008).

Hatchling: The newly born hatchling was naked with reddish body colour and the eyes were closed. The naked hatchling was also reported in Hawaii (Riper et al. 1979). The weight of the one-day hatchling in MNP was $2-4 \mathrm{~g}(2.7 \pm 0.7 \mathrm{~g})$, which was similar to Carleton and Owre (1975) reported in Florida. In MNP, the total body length of the hatchling was $41-44 \mathrm{~mm}(41.8 \pm 0.8 \mathrm{~mm})$. The length of the beak of the hatchling was 3-4 $\mathrm{mm}(3.4 \pm 0.5 \mathrm{~mm})$, and the head was $11-13 \mathrm{~mm}(11.9 \pm 0.8 \mathrm{~mm})$.

Hatching success: The hatching success was $63.46 \%$ in relation to eggs laid, which was higher than Li et al. (2015) findings (53.78\%) in southwest China.

Causes of eggs loss: A total of 19 eggs (36.5\%) were lost due to different causes (Fig. 3). Infertility was the prime factor of egg loss, followed by a heavy storm, predation, and stealing by local urchins. Local urchins used to steal the eggs for fun. Infertility, storms, parent desertion, and predation were causes of egg failure to hatch in Xishuangbanna Tropical Botanical Garden, southwest China (Li et al. 2015).

Nestling food and parental care: Both partners took care of nestling, fed, and cleaned the feces of nestlings. They fed the young, providing caterpillars, small insects, berries, and crushed fruits in MNP. Mazumdar and Kumar (2007) stated that both parents were involved in feeding the young and provided them regurgitated food in India. Li et al. (2015) stated that both invertebrate and plant food were provided to the nestlings in southwest China.

Fledging period: In MNP, the young fledged between 13-18 days (14.85 \pm 1.77 days) after hatching which was shorter (12 days) in Hawaii (Riper et al. 1979) but longer (16 days) in Florida (Florida Fish and Wildlife Conservation Commission 2003). The weight of the 
fledgling was $17.94-20.98 \mathrm{~g}(19.21 \pm 1.07 \mathrm{~g})$ with a total body length of $79.10-84.30 \mathrm{~mm}$ $(81.18 \pm 1.77 \mathrm{~mm})$. In MNP, the tail length was $10.96-12.88 \mathrm{~mm}(11.99 \pm 0.58 \mathrm{~mm})$, beak length was $15.45-16.05 \mathrm{~mm}(15.74 \pm 0.19 \mathrm{~mm})$, tarsus length was $19.90-20.80 \mathrm{~mm}$ $(20.31 \pm 0.29 \mathrm{~mm})$, and wing length was $47.13-51.10 \mathrm{~mm}(48.97 \pm 1.36 \mathrm{~mm})$.

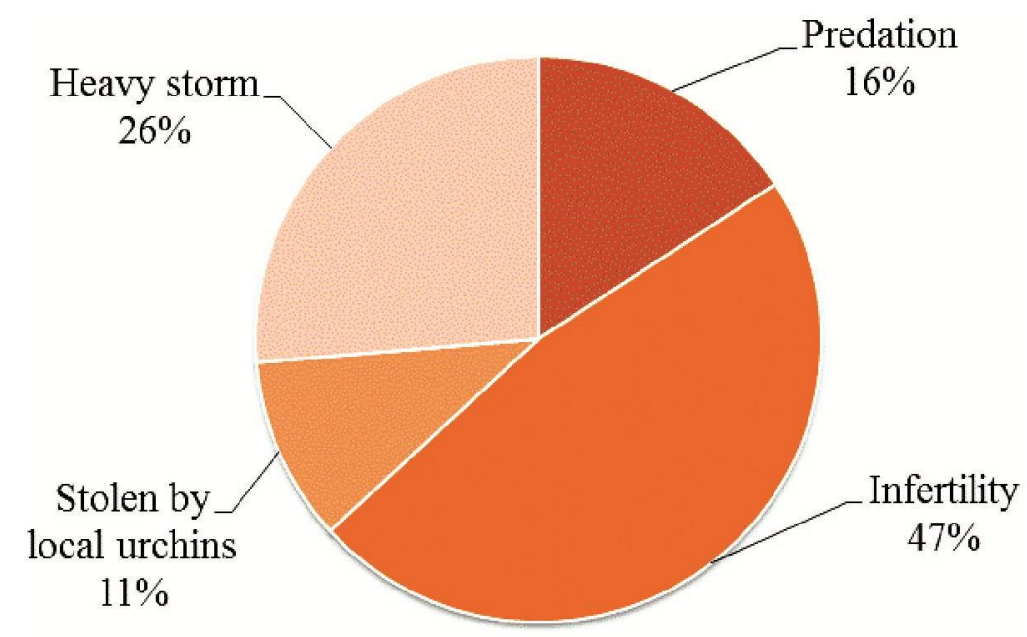

Fig. 3. Causes of egg loss during the nesting period of Red Whiskered Bulbul in Madhupur National Park.

Causes of nestling loss: A total of 6 nestlings were lost due to stolen (66.7\%) by local urchins' and nest parasites (33.3\%). The local urchins' collected fledglings for fun, which was the prime factor in decreasing breeding success. Nestlings died due to nest parasites, storms, and predation in Xishuangbanna Tropical Botanical Garden, southwest China, while predators are the main factor in nest failure (Li et al. 2015). Predators, diseases, size of nests, and chances of nestlings falling off their nests were the factors to death or mortality of fledglings in Lucknow, India (Mazumdar and Kumar 2007). Carleton and Owre (1975) mentioned that the common potential predators of the bulbuls are snakes, rats, cats and certain birds in Florida.

Breeding success: The fledging success was $51.92 \%$ in relation to eggs laid and $81.82 \%$ in relation to nestlings hatched. The fledging success was $63.63 \%$ in southwest China ( $\mathrm{Li}$ et al. 2015), and the overall nest success was 34.22\%. Mazumdar and Kumar (2007) reported that the nesting success was $72.2 \%$ in the Lucknow city center, but $80.5 \%$ among the periphery of the Lucknow city of India. 
The Red-whiskered Bulbul builds their nest in roadside bushes of the forest. Clearing of the forest is a regular phenomenon of our country, a threat to their nesting sites. Furthermore, cutting trees by the people to expand agricultural land and firewood collection also creates hazards for breeding habitats of the Red-whiskered Bulbul. Moreover, the regular practice of destruction of eggs and nestlings for fun by local urchins increases the mortality rates of this species. Therefore, an awareness campaign among the local people should be the best approach to conserve the habitat of the Redwhiskered Bulbul.

\section{Acknowledgements}

The authors are grateful to local field guide Mr. Nuru and other people of Madhupur National Park for their help during data collection.

\section{References}

Ali, S. and S.D. Ripley. 1971. Handbook of the birds of India and Pakistan. Vol. 6. Bombay, Oxford University Press.

Australian Museum. 2020. Red-whiskered Bulbul. http://australian.museum/learn/ animals/birds/ red-whiskered-bulbul-pycnonotus-jocosus/. Date accessed 4 July 2020.

Baker, E.C.S. 1922. The fauna of British India, including Ceylon and Burma. Vol. 1, second ed. London, Taylor and Francis.

Carleton, A.R. and O.T. Owre. 1975. The Red-whiskered Bulbul in Florida: 1960-71. The Auk. 92: 40-57.

Corlett, R.T. 1998. Frugivory and seed dispersal by birds in Hong Kong shrubland. Forktail. 13: 23-27.

Eguchi, K. and H.E. Amano. 2004. Invasive birds in Japan. Global Envtal. Res. 8(1): 29-39.

Florida Fish and Wildlife Conservation Commission. 2003. Florida's breeding bird atlas: A collaborative study of Florida's birdlife. http://www.myfwc.com/bba/. Date accessed 4 July 2020.

Islam, M.K., S. Saha, I. Mahmud, K. Mohamad, K. Awang, S.J. Uddin, M.M. Rahman and J.A. Shilpi. 2014. An ethnobotanical study of medicinal plants used by tribal and native people of Madhupur forest area, Bangladesh. J. Ethnophar. 151(2): 921-930.

Ismail, M. and M.M. Mia. 1973. Studies on some deciduous sal forests of Bangladesh; Ecology of Bangladesh Vegetation. Botanical Survey of Bangladesh, University of Dhaka.

IUCN Bangladesh. 2015. Red List of Bangladesh Volume 3: Birds. IUCN, International Union for Conservation of Nature, Bangladesh Country Office, Dhaka, Bangladesh. pp. $\mathrm{xvi}+676$.

Khan, S.I. and M.F. Ahsan. 2011. Birds of the Madhupur National Park, Bangladesh. Bangladesh J. Zool. 39(1): 49-63.

Khan, S.I. and M.F. Ahsan. 2015. Frugivorous birds and fruit plants in a deciduous forest in Bangladesh: a case study in the Madhupur National Park. Bangladesh J. Zool. 43(2): 173-187. 
Breeding biology of the red-whiskered bulbul

Li, H., M.X. Zhang, X.J. Yang, L.W. Cui and R.C. Quan. 2015. The breeding biology of RedWhiskered Bulbul (Pycnonotus jocosus) in Xishuangbanna, southwest China. Zool. Res. 36(4): 233-240.

Mazumdar, A. and P. Kumar. 2007. Nesting ecology of the Red Whiskered Bulbul at city center and periphery in Lucknow, Northern India. Том 16 Випуск: 98-102.

Monirujjaman and M.M.H. Khan. 2018.Wildlife Diversity of Madhupur National Park, Bangladesh. Jahangirnagar Univ. J. Biol. Sci. 7(1): 1-13.

Naher, H. 2012. Food habit, breeding biology and conservation issues of Kingfishers, Alcedo atthis and Halcyon smyrnensis. Ph.D. thesis. University of Dhaka. pp. xiii+228.

Naher, H., N.J. Sarker, M.K. Rahman and S.I. Khan. 2009. Breeding biology of the Little Cormorant Phalacrocorax niger (Pelecaniformes: Phalacrocoracidae) in Bangladesh. J. Threatened Taxa. 1(4): 221-225.

Pranty, B. 2010. Status and current range of Red-whiskered Bulbuls (Pycnonotus jocosus) in Florida. Florida Fie. Nat. 38(4): 146-149.

Riper, C.V.III, S.G.V. Riper and A. Berger. 1979. The Red-whiskered Bulbul in Hawaii. Wilson Bull. 91(2): 323-328.

Siddiqui, K.U., M.A. Islam, S.M.H. Kabir, M. Ahmad, A.T.A. Ahmed, A.K.A. Rahman, E.U. Haque, Z.U. Ahmed, Z.N.T. Begum, M.A. Hassan, M. Khondker and M.M. Rahman. (eds.). 2008. Encyclopedia of Flora and Fauna of Bangladesh, Vol. 26. Birds. Asiatic Society of Bangladesh, Dhaka. pp. 662.

Sotthibandhu, S. 2003. Territorial defense of the Red-whiskered Bulbul, Pycnonotus jocosus (Pycnonotidae), in a semi-wild habitat of the bird farm. Songklanakarin J. Sci. Technol. 25(5): 553-563.

(Revised copy received on 6.12.2020) 